\title{
Application of I-BOS System as Financial Reporting of BOS at SDN Sukanagara
}

\author{
Erick Febriyanto* $^{* 1}$, Qurotul Aini ${ }^{2}$, Aa Mustopa ${ }^{3}$ \\ ${ }^{1,2,3}$ Information Systems Study Program, Raharja University Faculty of Science and \\ Technology \\ Email: *1erick @ raharja.info, ${ }^{2}$ aini@ raharja.info, ${ }^{3}$ aamustopa@ raharja.info
}

\begin{abstract}
The School operational Assistance (BOS) is a government program for the provision of cost financing for basic education units as compulsory learning program executor. The particular purpose is to relieve the levy to relieve the burden of students. All schools are already listed in primary and secondary education principal data system. School is the most important element in determining the use of BOS funds because it is directly related to management. Based on the provisions applicable in the the Office of the BOS year 2012 BOS fund managed by the principal with the teacher or administrative personnel appointed as Treasurer. The current financial information on the world of education in which the data input collection is very complicated in the system of the process is very effective and efficient, in order to see data on the purchase or expense after that the Treasurer must Check back the statement of purchase and expense papers on the bank and all the reports of the paper have been made by the current Treasurer can be easily accessed by the leadership, one of which is presenting information using tables and in The workmanship system requires very high accuracy to ensure that any nominal information of money included in the table has to be ensured the truth is very less efficient. In order to facilitate the Treasurer in the recording of financial statements and leaders who perform a reduction in the information presented at SDN Sukanagara.
\end{abstract}

Keywords — Accounting, financial statements, Online applications, journals

\section{INTRODUCTION}

As the development of technology is rapidly and changes occur so significantly, the need for things closely related to the environment more and more life, in this research manual transaction data processing is not a problem, But that is a problem when many transactions are processed using a manual recording system. This will prevent the job, because of the number of transactions that must be in the input, as well as the stages to be created, if using the recording manually. Being assigned to the preparation of financial reporting is a Treasurer as a means to monitor the progress of an expenditure or income in a financial statement in a report.

Where a change is needed in various aspects e.g. the form of information presentation, so that information can be effective and easy to understand the source of information from a financial report is made much guidance in the retrieval of a decision for Creditors, economic observers, shareholders, Governments and education in accordance with the interests of the existing, as well as a detailed guideline on each operational achievement of the company's financial ratios analysis. With the financial report, there will be a description of how the company's development, so that the interested in the company's development can conduct analysis of all financial data contained in the report Financial. 
The risk of error occurs when the preparation of financial statements is greater when done manually and the data was assessed still less accurate, hence the utilization of information technology is a computer can accelerate the things that are Especially in the calculation of the field of reporting on the Treasurer to the service. In each financial report must also be called a balance or so-called balanced, the meaning is that it can create and generate measurable financial statements from two points of view in a balanced manner both internal and external Long and short term.

The report of income that has been processed in such a way is one of the important points in finance as a condition of completeness of income making. The revenue report that now runs the process is still processed manually where a treasurer must recap the data from the set of files that have been prepared such as the receipts into the Excel form, then calculated using the calculator or formula contained in the Excel. While the current era of globalization develops so rapidly, and has penetrated into the field of financial calculations in line with users who are increasingly aware of the importance of science, especially the field of technology.

A variety of ways can be done so that the quality of available reports is increasing one of them by utilizing today's technology. Where a financial report information or BOS and BOSDA reporting is said to be high quality if the information used as a supporter of all individual transactional activities or the company is equipped with a system control that is Maximum to be able to monitor performance, so that the resulting and displayed report data can anticipate the possibility of a mistake or a fatal error later in the day. While the human resources are required to be more creative and can utilize the development of the technology to the fullest as the needs of the longer increasingly complicated. Where changes are felt is necessary in various aspects such as the form of information presentation, so that information can be assessed effective and can be easily understood. I-BOS is an Online financial reporting application in the field of financial reports on Treasurer with full financial statements such as, financial balance sheet, cash flow, income statement, and others. I-BOS can be accessed by using $\mathrm{WiFi}$ or connection via internet wherever the user is located.

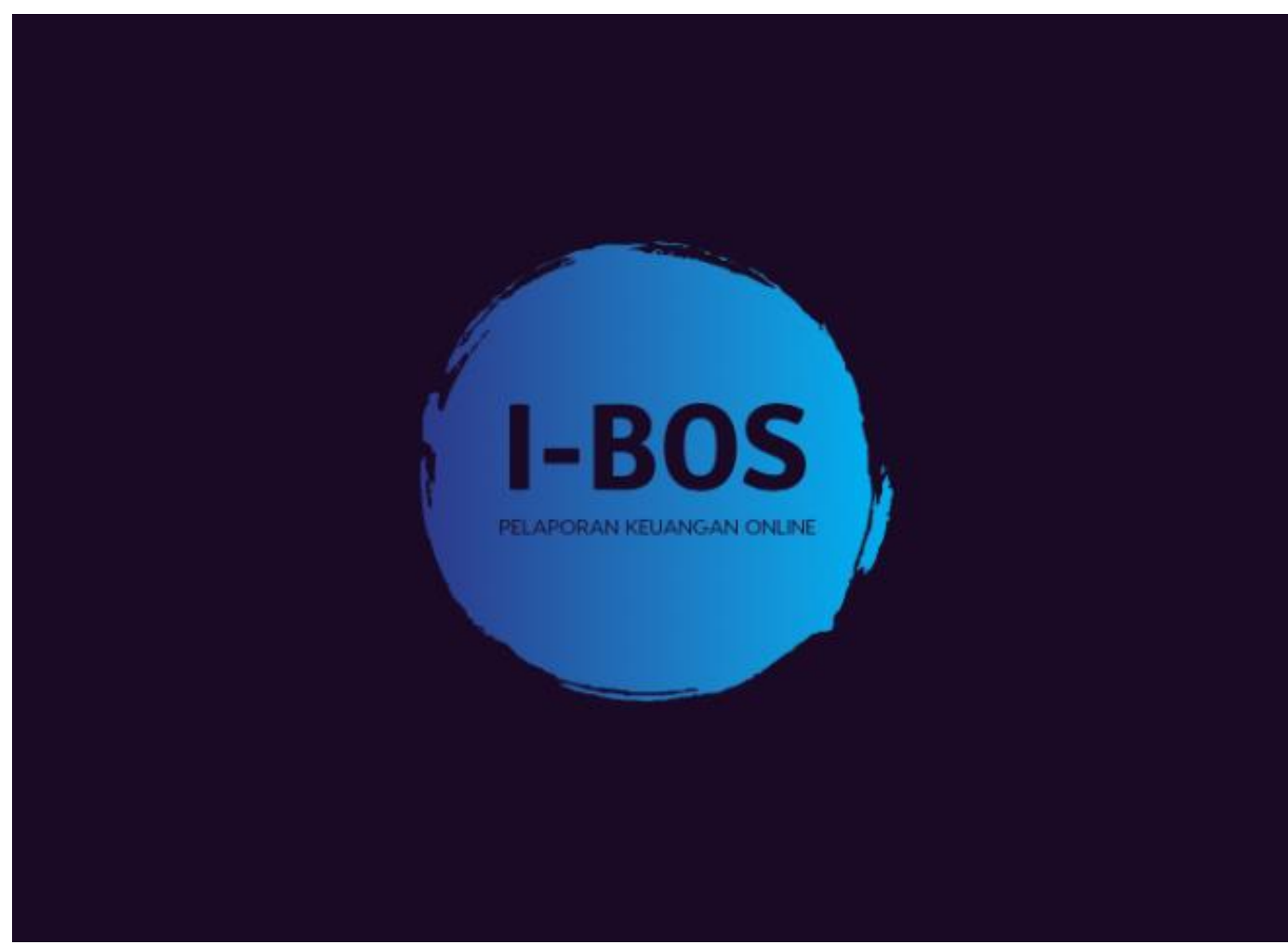

Figure 1. I-BOS Logo 
As a form of facilities to simplify the recording of financial statements, there has been an I-BOS (Online Financial report application). Where I-BOS (Online financial statements application) is a newborn application and is still in the development process which is an application supporting the recording of financial reports that can be accessed Online, it is very important to provide a solution and is one of the tools that are good enough to handle the system not yet optimal (manual). For the public, especially the treasurer of the education world of course with the presence of an Online financial reporting application becomes so important because it can easily manage the finances in a detailed, fast, precise and can be very helpful without passing or there are many errors. One method of controlling an Online-based system is to authorize based on certain criteria for users, this control is used as a preventive effort on the undesirable.

I-BOS has thought about this well where data is secured with equivalent or stronger technology than the Bank has used. Use AES-256 encryption so that the existing data cannot be viewed by unauthorized parties. The 2056-bit SSL certificate has also been used to secure Internet connection. With the security facilities provided it is also expected to provide information more quickly and accurately directly to the hands of the office if already have an account.

The first problem faced is the number of transactions that are very much every day with the process of data processing is still manually. The processing of such data becomes very inefficient and effective, because it will most likely be errors in the calculation and the number of stages to be done.

To prove that the income and expense reports are in line with existing transactions then the Treasurer must carry a file such as receipts proving that all transactions are in the input and reported well to be given to the head of office so that the report can be verified in the data correctness. The data reduction is still done manually where every day at least 200 transactions are even more which takes 1 to several hours to perform calculations to get the total appropriate and precise (balance/fit).

\section{RESEARCH METHOD}

The Use Case diagram illustrates the expected functionality of a system. The emphasis is "what" the system does, and not the "how". A use case represents an interaction between an actor and a system. The following process describes the processes associated with the actor and the system. Such interactions can be illustrated with the use case diagram. The following is the use case diagram for the BOS report system at SDN Sukanagara Kabupaten Tangerang, and the following.

After the data collection method has been completed, what will be done next is the design concept stage using UML (Unified Modeling Language). Below is an elaboration of the design method using the UML system that is running:

\section{A. Use Case Diagram of The Running System}

The Use Case diagram illustrates the expected functionality of a system. The emphasis is "what" the system does, and not the "how". A use case represents an interaction between an actor and a system. The following process describes the processes associated with the actor and the system. Such interactions can be illustrated with the use case diagram. The following is the use case diagram for the BOS report system at SDN Sukanagara Kabupaten Tangerang, and the following. 


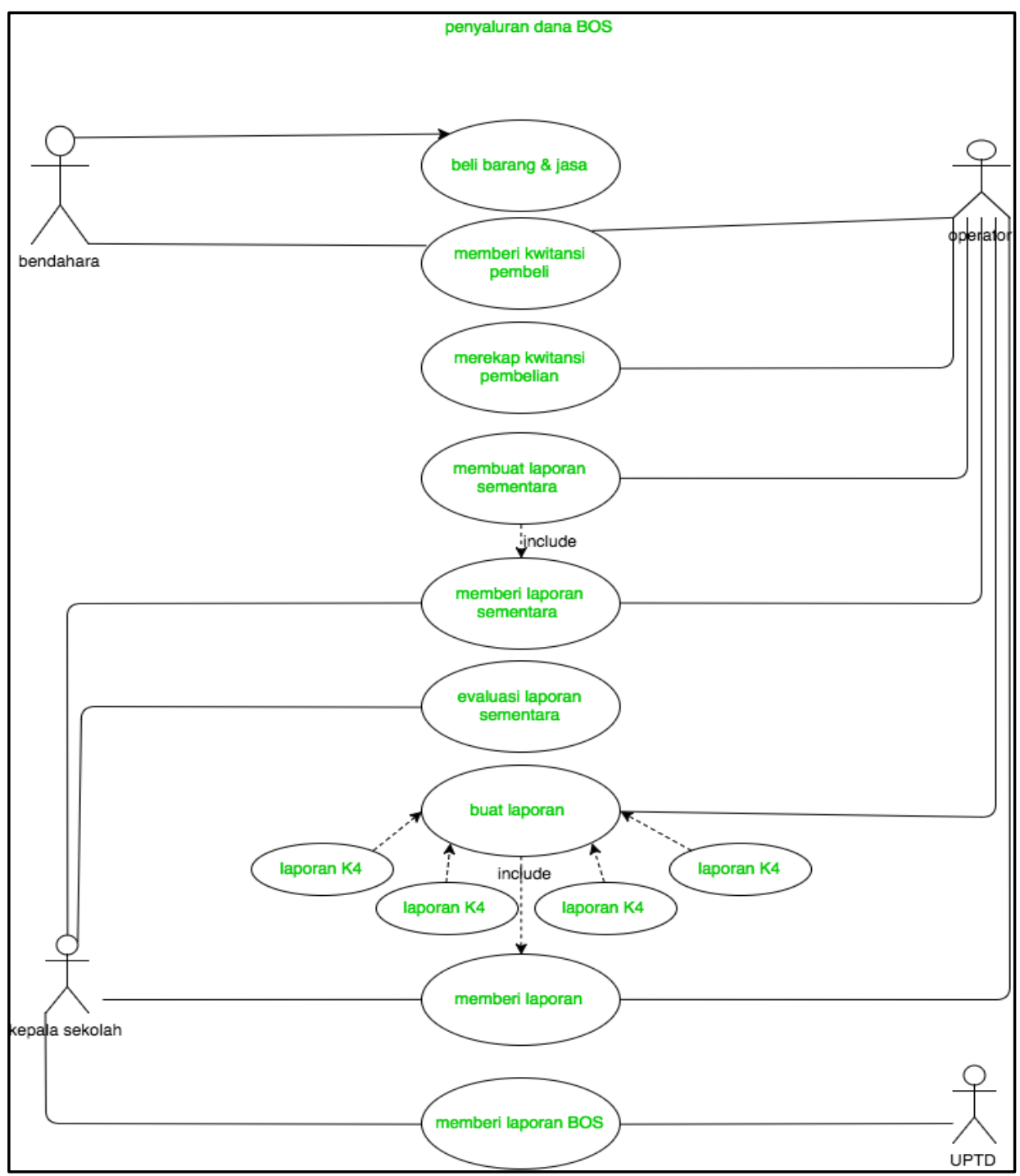

Figure 2. Use Case Running System

In the Use Case Diagram above, there are:

1) 1 (one) system, i.e. boss Report system

2) 9 (Nine) use cases, namely:
a) Buy School Needs
b) Submit the Receipt
c) Rebrand the receipt
d) Create a temporary report
e) Submit temporary reports
f) Analyzing the temporary report

g) Creating reports including the creation of reports K4 (Helper book Bank), K7(realization of use of funds per budget type), K7a (recapitulation of the realization of the use of Bos funds, K8 (recapitulation of Fund usage report).

h) Provide reports

i) Receive boss

3) 4 (four) actors with their respective functionalities as follows:

a) Treasurer: Is the financial part of the boss funds in charge of managing the finances of the bosses received from the government. 
b) Operator/TU: is to create a report and return the result of the use of BOS funds.

c) Principal: Is the school leader who conducts regular control of the activities of the school's operational assistance, so that the Chairman is entitled to receive BOS funds report.

d) UPTD: District level implementing units, in charge of controlling schools within the organizational structure of UPTD.

\section{B. Activity Diagram Current System Diagram System}

Describes the various activities in the system that are being designed, how each one begins, the possible decision, and how they end. The Activity Diagram can also illustrate a parallel process that may occur on some executions. The Activity diagram is a special diagram state, where most of the State is action and most of the transitions are triggered by the completion of the previous state (Internal Processing). Therefore the activity diagram does not describe the internal behaviour of a system (and the interactions between subsystems) in an exact way, but rather illustrates the processes and activity paths from the upper level in general.

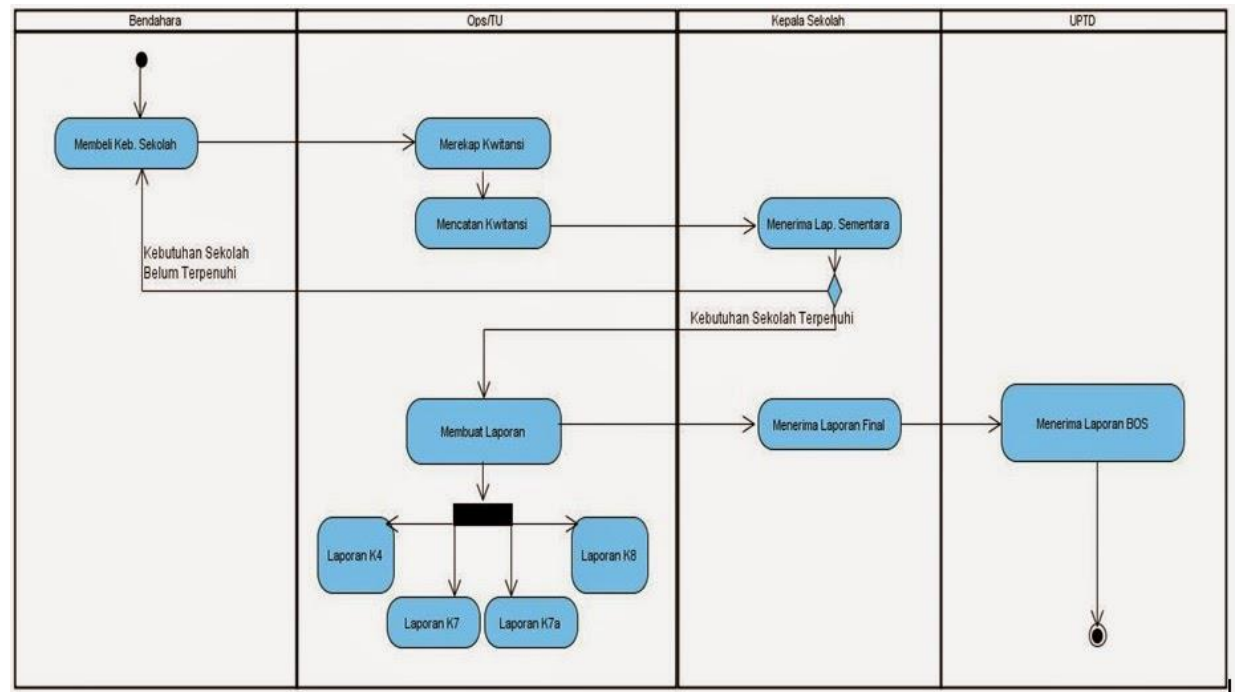

Figure 3. Activity That Runs

In the Activity Diagram system library above:

1) 1 (one) Initial Node

2) 7 (seven) actions, including:

a) Buying school needs.

b) Reaps the receipts.

c) Recording

d) Receipts

e) Receive

f) Reports While

g) Creating a report

3) 1 (one) Final Node Activity

Activity flow illustrated in the diagram above is the Treasurer bought the needs of the school then give the receipt of the results of the purchase to Ops/Tu and Ops/Tu group receipts based on the type of purchase such as the thing recorded in the Juknis BOS, after which it recap the receipt and proceed with giving Lap. Meanwhile, to the principal and also conducted the purchase analysis, if there is a deficiency in meeting the needs of the school, then the 
principal will inform Ops/Tu about the shortcomings, and forwarded the report to the school treasurer to immediately meet the needs of the school in accordance with what was instructed by the school principal, but if the school needs have been fulfilled, then OPS/Tu will immediately make the report K4 (Bank Helper book), K7 Each type of budget), K7a (recapitulation of the realization of the use of Bos funds, K8 (recapitulation of the Fund usage report) in which the reporting refers to the current BOSS Juknis.

\section{RESULTS AND DISCUSSION}

Already described in the problem above the main point of the problem is the process of logging the report or the input that is still manual and still possible the existence of nominal errors and description of the description can be concluded the problem Used by an I-BOS (Online Financial report application) with the following threads:

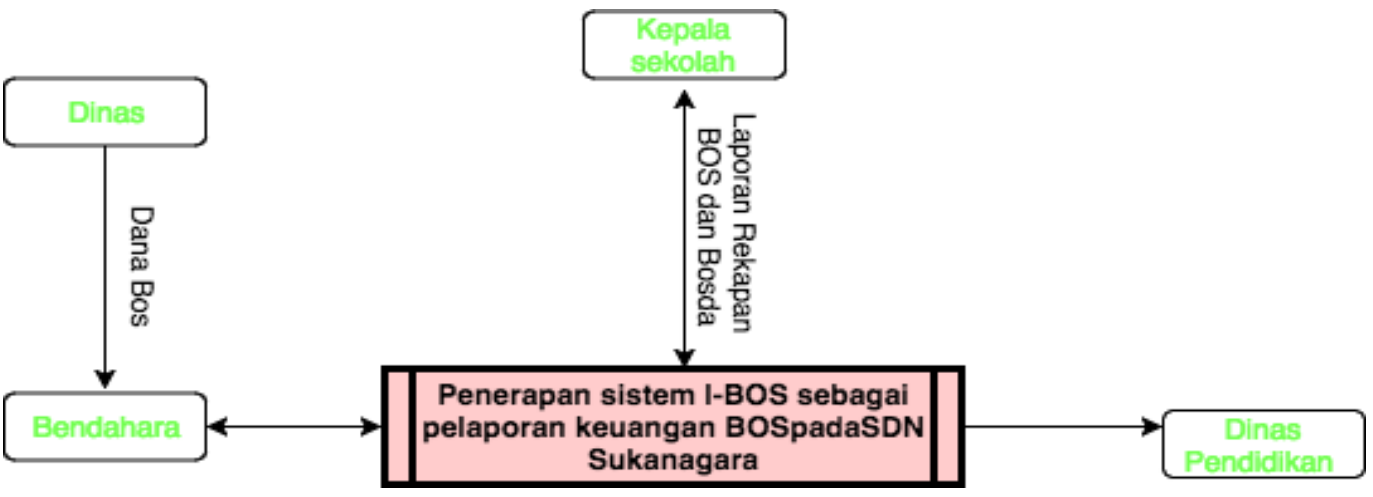

Figure 4. The Flow of Funds on Treasurer

It is a system flow on I-BOS and the groove can be explained that to do the process of logging the revenue can be done Online and fast. With IBOS process of revenue recording can be done Online and independently by the treasurer. So whenever and wherever can be done quickly record the income, then the report will be verified the accuracy by the principal and directly to the Education office. Then began to be made an I-BOS with the name of the journal (Application of I-BOS system as financial reporting BOS at SDN Sukanagara).

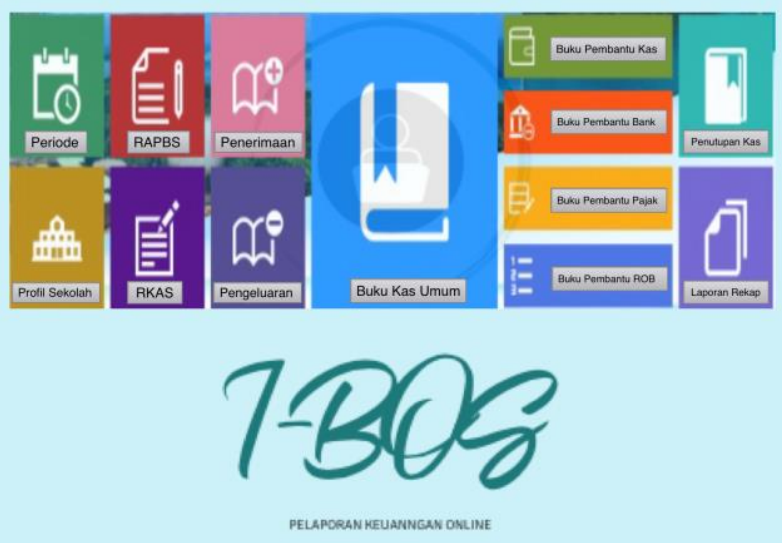

Figure 5. Dashboard View of I-BOS 
The I-BOS dashboard display contains the information of all financial statements with the data that has been input into the web. The reporting Menu contained in the application has been implemented in Sukanagara State elementary School in support of the implementation of financial statements and financial monitoring of one of the goods inventory reports. Head of finance, treasurer or anyone who already has an account in I-BOS can see and read even the processing of existing transaction data starts from preparing the transaction data in Excel, access the I-BOS application using the account already Registered, accessing the reporting menu contained in the BOS, selecting the Data Input menu, adjusting the data to be ready to report with the Web form that has been provided by the Treasurer through the I-BOS application, ensuring the data to be reported is correct, then the transaction data, and once it is entered and reported it will be displayed all reports data that has been reported neatly. The following will be described several examples of test results and implementation of I-BOS based on factual transaction data existing at SDN Sukanagara as a research and trial implemented.

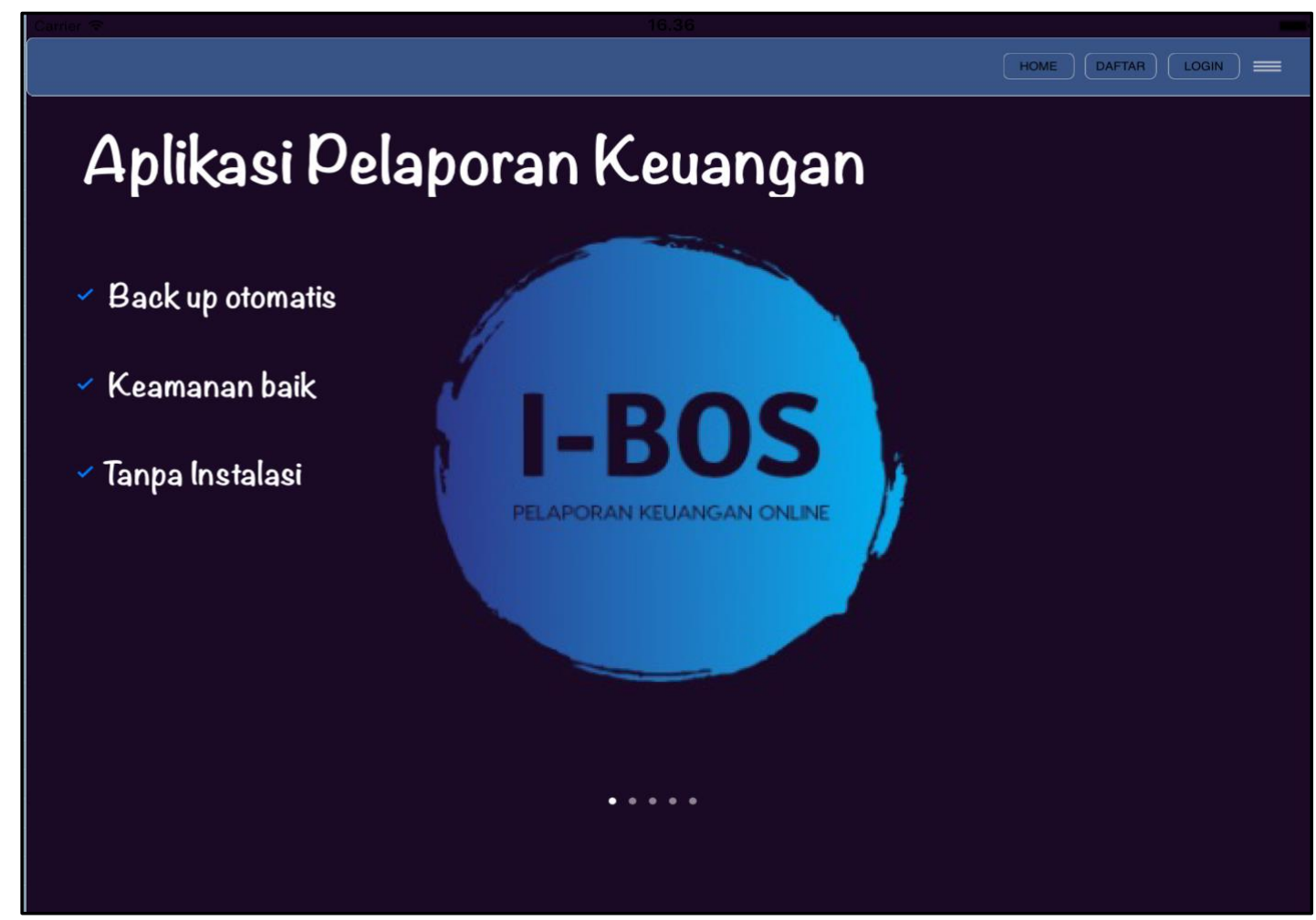

Figure 6. Home View on Journals

It is a view of the home Journal that is used to be entered into the journal program 


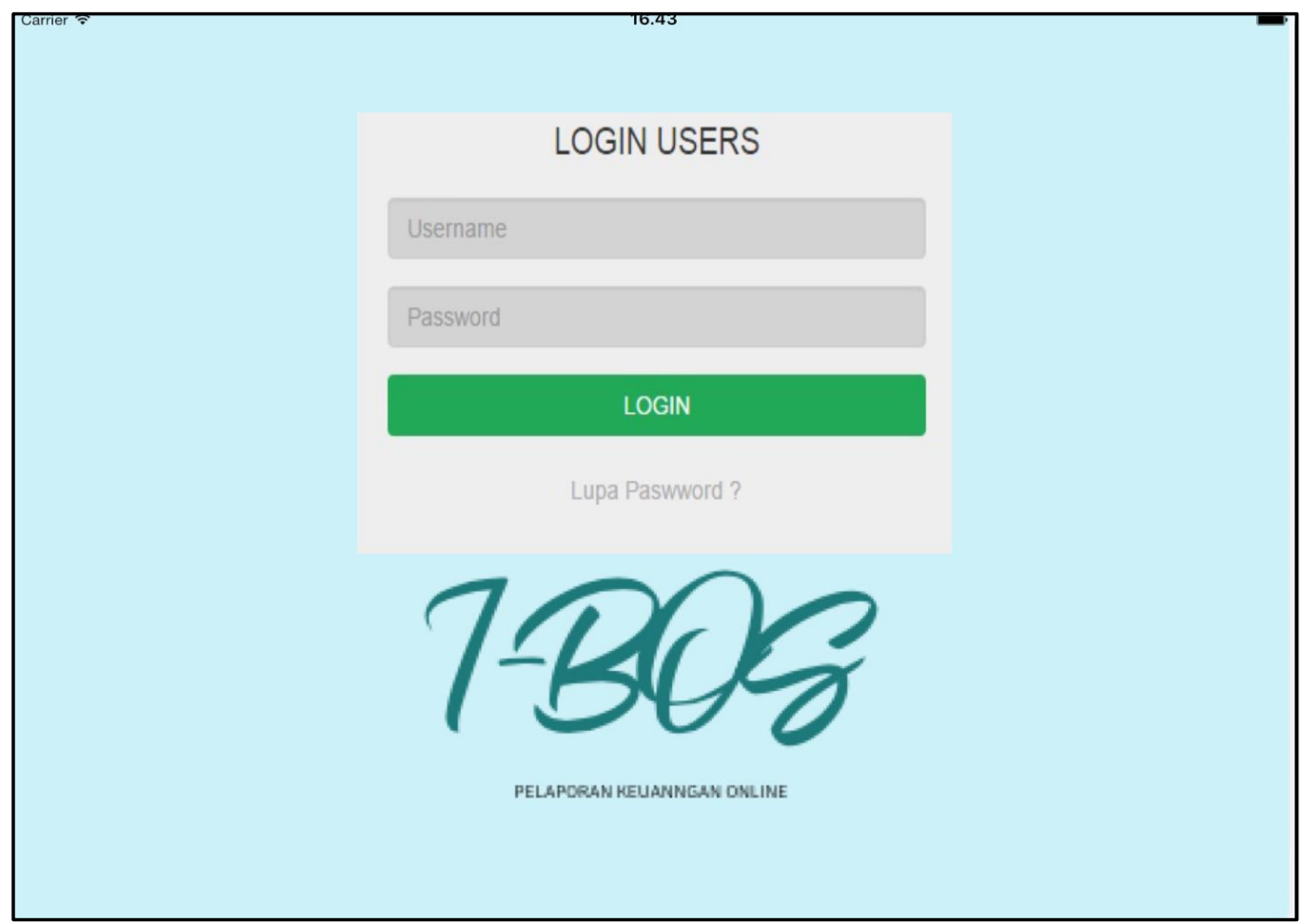

Figure 7. Login View on Journal

It is a login view of the journal using email and password already registered

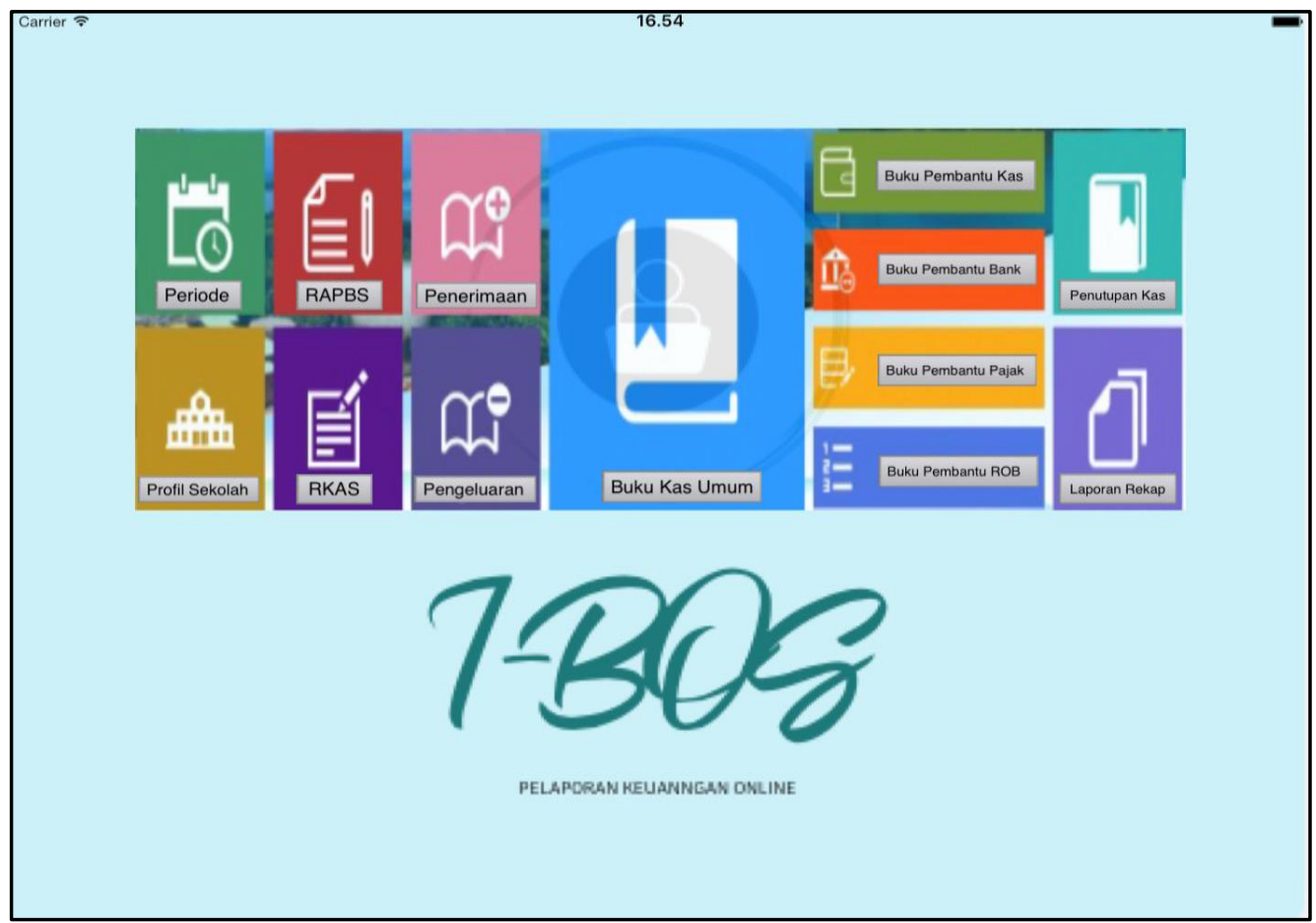

Figure 8. Is the menu display

In I-BOS There are 13 tabs that can be accessed by the user of the I-BOS account owner where one of them is the Financial report tab used to record revenue and expenses. 


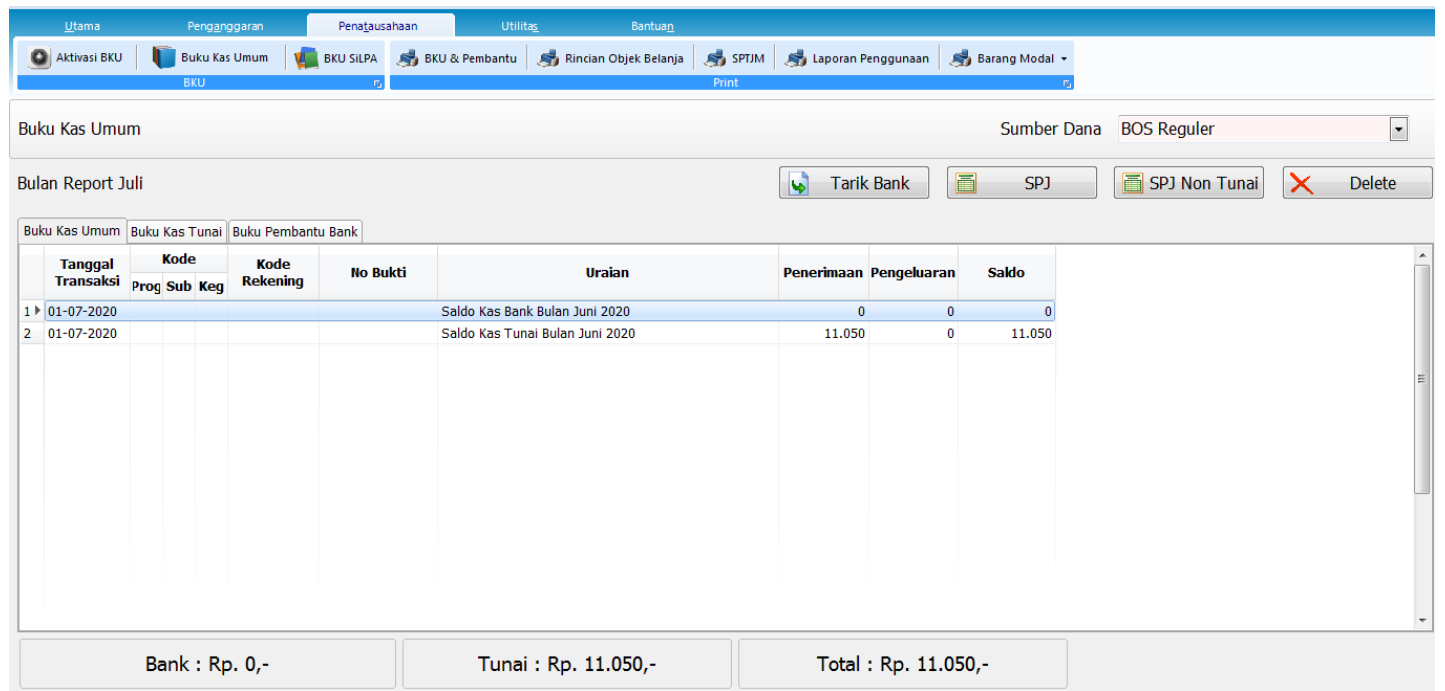

Figure 9. Display of Process Data Input Into Program I-BOS

In the picture is needed data from the treasurer so that it can be recorded in the program, according to the expenditure and income made by the Treasurer, then if the data is confirmed true then we can input so that the data we enter can be recorded properly in this program so that the data that has been in the same automatic input or will automatically balance/fit itself with other data.

\section{CONCLUSION}

Based on the discussion and results of the research discussed earlier as well as studying the problems of the information system of the School Operational Assistance Fund (BOS) that exists at SD Negeri Sukanagara, then it can be withdrawn as follows:

1) Information System for the information distribution of school operational assistance in SD Negeri Sukanagara still there are many problems in making reports and information related to the use of the school's Operational Assistance Fund. Especially at the time of making the report, in its inaction there is no mechanism or system built to manage the information of the school's Operational aid fund, so it is not structured in the report generation. This results in a long time and patience and thoroughness in the making of this report.

2) Some of the obstacles that occur are spending too much paper to print a temporary report, which is a report that is only done recording based on the 13 components in the BOS technical guidebook. So if the budget spend has not fulfilled the target against the 13 components that are in the BOS Technical manual will be re-recording and re-grouping the receipt of the purchase of goods and services in accordance With 13 boss spending components.

3) To address some of the issues expressed in the first and second conclusions then the authors propose to conduct a system of information delivery of the school's Operational Assistance Fund, with this system assisting the school operator or the administration and The principal in recording all spending using the school's operational grants, no longer need a temporary report and re-registration and through this system the principal can evaluate the spending of operational aid funds Schools Have been fulfilled or have not been fulfilled in accordance with the Government decree on the Technical Assistance guide of school operations. 
Conclusion to the research objectives, management of the school's Operational assistance fund should be processed with good management therefore with this system is the solution of the problem. This research is conducted to know the description of the School Operational Assistance Fund distribution System (BOS) what is already running according to the procedure or vice versa, for that to meet the Program 8 National Education Standards Fund BOS must be precise target In use. Implementing the knowledge gained from the learning process at Raharja College by creating a system of information about the school's operational assistance to develop the skills. Conclusion to the research benefits. By doing this research can be useful for SDN Sukanagara Cikupa District Tangerang Regency, to accelerate the performance of officers in performing the work and to facilitate the development of reports and more controlled to Evaluate the use of the school's operational assistance budget and provide knowledge to human resources on computerized systems especially in educational environments and in particular treasurer.

\section{SUGGESTED}

a) Periodic evaluation and database backfill as well as maintenance of application programs are important to the proposed system to ensure the program is running well and as expected.

b) Periodic evaluation and database backfill as well as maintenance of application programs are important to the proposed system to ensure the program is running well and as expected.

c) The need for training for school treasurers in the operation of computer so that there is a user backup if the school operator or the business is absent to attend in schools. Once the system can be implemented and implemented well, in the future it needs to be done a new development system and more in accordance with the development of technology.

\section{REFERENCES}

[1] Rerung, Rintho R. 2018. E-Commerce, Menciptakan Daya Saing Melalui Teknologi Informasi. Yogyakarta: Deepublish.

[2] Gonzales, R., P. 2004, Digital Image Processing (Pemrosesan Citra Digital), Vol. 1, Ed.2, diterjemahkan oleh Handayani, S., Andri Offset, Yogyakarta.

[3] Wyatt, J. C, dan Spiegelhalter, D., 1991, Field Trials of Medical Decision-Aids: Potential Problems and Solutions, Clayton, P. (ed.): Proc. 15th Symposium on Computer Applications in Medical Care, Vol 1, Ed. 2, Mc Graw Hill Inc, New York.

[4] Yusoff, M, Rahman, S., A., Mutalib, S., and Mohammed, A., 2006, Diagnosing Application Development for Skin Disease Using Backpropagation Neural Network Technique, Journal of Information Technology, vol 18, hal 152-159.

[5] Wyatt, J. C, Spiegelhalter, D, 2008, Field Trials of Medical Decision-Aids: Potential Problems and Solutions, Proceeding of 15th Symposium on Computer Applications in Medical Care, Washington, May 3.

[6] Prasetya, E., 2006, Case Based Reasoning untuk mengidentifikasi kerusakan bangunan,

[7] Tesis, Program Pasca Sarjana Ilmu Komputer, Univ. Gadjah Mada, Yogyakarta.

[8] Ivan, A.H., 2005, Desain target optimal, Laporan Penelitian Hibah Bersaing, Proyek Multitahun, Dikti, Jakarta.

[9] Hamdani, H., Haviluddin, H., \&amp; Darmawangsa, N. S. (2016). Rancang Bangun Web Service Untuk Penjualan Tiket Bus Damri. Informatika Mulawarman, 6(2), 54-63.

[10] Prihati, Y., Listijo, H., Saputro, D. T., \&amp; Ritonga, Y. (2017). Aplikasi Social ECommerce Pada Prediss Group. KOMPUTAKI, 1(1). 
[11] Dedi, D., Sirait, R. J., \&amp; Budiman, A. (2016). Pengembangan Sistem Informasi Penjualan dan Pemasaran (Studi Kasus di PT SAI Indonesia Cabang Tangerang). Jurnal Sisfotek Global, 6(1).

[12] Aris, A., Jayanti, S. D., Setyowati, M., Wahyuni, W., \& Kusuma, C. (2017). Aplikasi Sistem Informasi Penyaluran Dana Bantuan Operasional Sekolah Berbasis Web Pada SD Negeri Cimone 4 Tangerang. E-Proceedings KNS\&I STIKOM Bali, 19-24..

[13] Amborowati, A., \& Marco, R. (2016). Analisis Pengelolaan Dan Monitoring Dana Bantuan Operasional Sekolah (BOS) Menggunakan Sistem Informasi Berbasis Website Pada SLTP Di Daerah Istimewa Yogyakarta. Data Manajemen dan Teknologi Informasi (DASI), 17(1), 6-14..

[14] Anggraini, R. D. (2001). Transparansi, partisipasi, dan akuntabilitas pengelolaan anggaran dana BOS dalam program RKAS di SDN Pacarkeling VIII Surabaya. Sumber, 21(23), 21-77.

[15] Mamonto, S. (2016). VALUASI PROGRAM BANTUAN DANA OPERASIONAL SEKOLAH PADA SEKOLAH DASAR NURUL HUDA II YAPIS JAYAPURA. JIAP: Journal of Administration Science and Governmental Science, 1(1).

[16] Putri, M. A. (2015). The Management of School Operational Support Funds (Dana BOS): Case Study of SMP Negeri 16 Yogyakarta Academic Year 2013/2014 (Doctoral dissertation, YOGYAKARTA STATE UNIVERSITY).

[17] Radiyanto, R., Astriyani, E., \& Juliyawati, E. (2015). RANCANGAN SISTEM INFORMASI LAPORAN DANA BANTUAN PERSONAL PENDIDIKAN MELALUI PROGRAM TANGERANG CERDAS PADA DINAS PENDIDIKAN DAN KEBUDAYAAN KOTA TANGERANG. SENSI Journal, 1(1), 67-75.

[18] Rahardja, U., Aini, Q., \& Hardini, M. (2018). PENERAPAN SOFTWARE AKUNTANSI ONLINE SEBAGAI PENUNJANG PENCATATAN LAPORAN KEUANGAN. SISFOTENIKA, 8(2), 176-187 